\title{
A New Steroidal Glycoside and a New Phenyl Glycoside from a Ripe Cherry Tomato
}

\author{
Masateru Ono, ${ }^{*, a}$ Yuki Shiono, ${ }^{a}$ Yoshihiro Yanai, ${ }^{a}$ Yukio FuJiwara, ${ }^{b}$ Tsuyoshi IkedA, ${ }^{b}$ and \\ Toshihiro NOHARA ${ }^{c}$ \\ ${ }^{a}$ School of Agriculture, Tokai University; 5435 Minamiaso, Aso, Kumamoto 869-1404, Japan: ${ }^{b}$ Faculty of Medical and \\ Pharmaceutical Sciences, Kumamoto University; 5-1 Oe-honmachi, Kumamoto 862-0973, Japan: and ${ }^{c}$ Faculty of \\ Pharmaceutical Sciences, Sojo University; 4-22-1 Ikeda, Kumamoto 860-0082, Japan. \\ Received July 8, 2008; accepted July 28, 2008; published online July 29, 2008
}

\begin{abstract}
A new steroidal glycoside and a new phenyl glycoside have been isolated from a ripe cherry tomato [Lycopersicon esculentum var. cerasiforme (DunAL) ALEF., Solanaceae] along with two known steroidal alkaloid glycosides, esculeoisides $A$ and $B$, and five aromatic compounds, zizibeoside $I$, benzyl alcohol $\beta$-gentiobioside, rutin, methyl caffeate, and phenylalanine. Their chemical structures were determined on the basis of spectroscopic data as well as chemical evidence.
\end{abstract}

Key words Lycopersicon esculentum; cherry tomato; Solanaceae; steroidal glycoside; phenyl glycoside

In previous papers, ${ }^{1-4)}$ we reported the isolation and structural elucidation of a steroidal alkaloid glycoside, esculeoside A, from a ripe pink color-type tomato (Lycopersicon esculentum, Momotaro, Solanaceae), a solanocapsine-type glycoside, esculeoside B, from a ripe red color-type tomato ( $L y$ copersicon esculentum, Italian San Marzano), esculeosides $\mathrm{A}, \mathrm{B}, \mathrm{C}$, and $\mathrm{D}$ and lycoperoside $\mathrm{G}$ from a ripe cherry tomato [Lycopersicon esculentum var. cerasiforme (DuNAL) Alef.], and a pregnane glycoside, tomato-pregnane, from an overripe cherry tomato. As part of our ongoing study on the chemical constituents of tomatoes, the present study deals with the isolation and structural characterization of a new steroidal glycoside and a new phenyl glycoside along with two known steroidal alkaloid glycosides and five known aromatic compounds from ripe cherry tomatoes.

A ripe cherry tomato was crushed and extracted with $\mathrm{MeOH}$. The $\mathrm{MeOH}$ extract was successively subjected to Diaion HP-20, Sephadex LH-20, Chromatorex ODS, and silica gel column chromatography, as well as HPLC on C18, C8, and polyamine to yield three steroidal glycosides $(\mathbf{1}, \mathbf{3}, \mathbf{4})$ and six aromatic compounds $(\mathbf{2}, \mathbf{5}-\mathbf{9})$.

Compounds $3-9$ were identified as esculeoside A $(\mathbf{3}),{ }^{1,2)}$ esculeoside B (4), ${ }^{2)}$ zizibeoside I (5), ${ }^{5)}$ benzyl alcohol $\beta$-gentiobioside (6), ${ }^{6}$ rutin (7), methyl caffeate (8), and phenylalanine (9), respectively, based on the comparison of their physical and spectral data with authentic or previously reported samples (Fig. 1).

Compound 1 was obtained as an amorphous powder, and its positive FAB-MS exhibited an $[\mathrm{M}+\mathrm{Na}]^{+}$ion peak at $\mathrm{m} / \mathrm{z}$ 1367. The molecular formula of $\mathbf{1}$ was determined to be $\mathrm{C}_{61} \mathrm{H}_{100} \mathrm{O}_{32}$ by using high-resolution (HR)-positive FAB-MS. In the ${ }^{1} \mathrm{H}$-NMR spectrum of $\mathbf{1}$, signals due to two tertiary methyl groups $(\delta 0.70,0.66)$, two secondary methyl groups

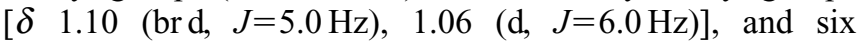
anomeric protons $[\delta 5.57(\mathrm{~d}, J=8.0 \mathrm{~Hz}), 5.19(\mathrm{~d}, J=8.0 \mathrm{~Hz})$, $5.16(\mathrm{~d}, J=8.0 \mathrm{~Hz}), 4.94$ (d, $J=6.0 \mathrm{~Hz}), 4.93$ (d, $J=7.5 \mathrm{~Hz})$, $4.77(\mathrm{~d}, J=8.0 \mathrm{~Hz})]$ were observed. The ${ }^{13} \mathrm{C}$-NMR spectrum of 1 exhibited 61 carbon signals including two carbonyl carbons $(\delta 218.5,214.1)$ and six anomeric carbons $(\delta 105.0$, $104.6,104.6,104.5,104.3,102.4)$. From these data, 1 was concluded to be a steroidal hexaglycoside. Acidic hydrolysis of 1 yielded D-glucose, D-galactose, D-xylose, and L-arabinose, which were identified by using optical rotation chiral detection in the HPLC analysis, along with several unidentified artificial aglycones. A detailed analysis of the ${ }^{1} \mathrm{H}-$ and ${ }^{13} \mathrm{C}$-NMR signals of $\mathbf{1}$ using the ${ }^{1} \mathrm{H}-{ }^{1} \mathrm{H}$ correlation spectroscopy (COSY), heteronuclear multiple-quantum coherence (HMQC), heteronuclear multiple-bond correlation (HMBC), and total correlation spectroscopy (TOCSY) indicated that the planar structure of 1 was a 3,26-bisdesmoside of 3,26-dihydroxy cholestan-16,22-dione, as shown in Fig. 2. Further, the ${ }^{13} \mathrm{C}-\mathrm{NMR}$ data of $\mathrm{C}-1-\mathrm{C}-11$ and $\mathrm{C}-19$ of the aglycone (Ag) moiety and sugar chain attached to $\mathrm{C}-3$ of $\mathrm{Ag}$ were superimposable on those of $3^{2}$; on the other hand, those of C-12-C-18 and C-20 $-\mathrm{C}-27$ of the Ag moiety were quite similar to those of anguivioside XV (10). ${ }^{7)}$ The remaining sugar chain, which was attached to $\mathrm{C}-26$, was determined to be an $\alpha$-L-arabinopyranosyl-( $1 \rightarrow 6)$ - $\beta$-D-glucopyranosyl group based on the following evidence. The ${ }^{13} \mathrm{C}$-NMR spectrum of 1 exhibited signals due to a terminal $\alpha$-L-arabinopyranosyl group $(\delta 105.0,72.0,74.0,68.8,66.3)^{8)}$ and a $\beta$-D-glucopyranosyl group $(\delta 104.5,74.8,78.0,71.0,76.7,69.4)$, which indicated the glycosylation shifts ${ }^{8,9)}$ at C-5 and C-6 with magnitudes $-2.0 \mathrm{ppm}$ and $+6.5 \mathrm{ppm}$, respectively, as compared to those of 10. Further, the values of the coupling constants of the anomeric proton signals confirmed the mode of glycosidic linkages of the glucopyranosyl group and the arbinopyranosyl group to be $\beta$ and $\alpha$, respectively. From these data, the structure of 1 was determined to be $3-O-\beta$ lycotetraosyl 3 $\beta, 26$-dihydroxy cholestan-16,22-dione $26-O$ $\alpha$-L-arabinopyranosyl-( $1 \rightarrow 6)$ - $\beta$-D-glucopyranoside.

Compound 2 was obtained as an amorphous powder. The positive FAB-MS of 2 exhibited an $[\mathrm{M}+\mathrm{Na}]^{+}$ion peak at $\mathrm{m} / \mathrm{z}$ 457, and the molecular formula of 2 was determined to be $\mathrm{C}_{18} \mathrm{H}_{26} \mathrm{O}_{12}$ by using HR-positive FAB-MS. The ${ }^{1} \mathrm{H}-\mathrm{NMR}$ spectrum of 2 exhibited signals due to four aromatic protons for an $\mathrm{AA}^{\prime} \mathrm{BB}^{\prime}$ pattern $[\delta 7.46(\mathrm{~d}, J=7.0 \mathrm{~Hz}), 7.14(\mathrm{~d}, J=7.0$ $\mathrm{Hz})]$ and two anomeric protons $[\delta 5.40(\mathrm{~d}, J=8.0 \mathrm{~Hz}), 5.36$ $(\mathrm{d}, J=7.5 \mathrm{~Hz})]$. The ${ }^{13} \mathrm{C}-\mathrm{NMR}$ spectrum of 2 was similar to that of 5, except for the presence of signals due to a 4-hydroxyphenyl group and the absence of signals due to a benzyl group. On acidic hydrolysis, 2 yielded hydroquinone and 

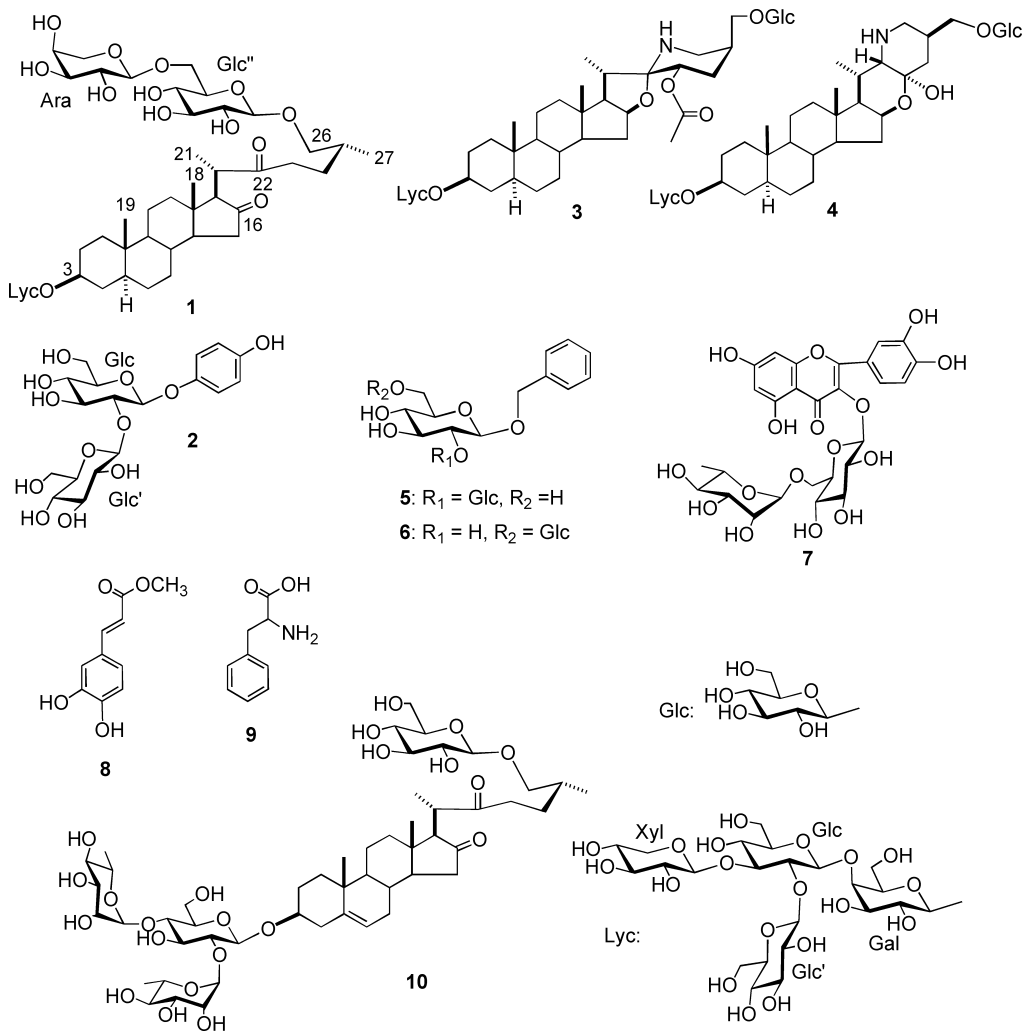

Fig. 1. Structures of $\mathbf{1}-\mathbf{1 0}$

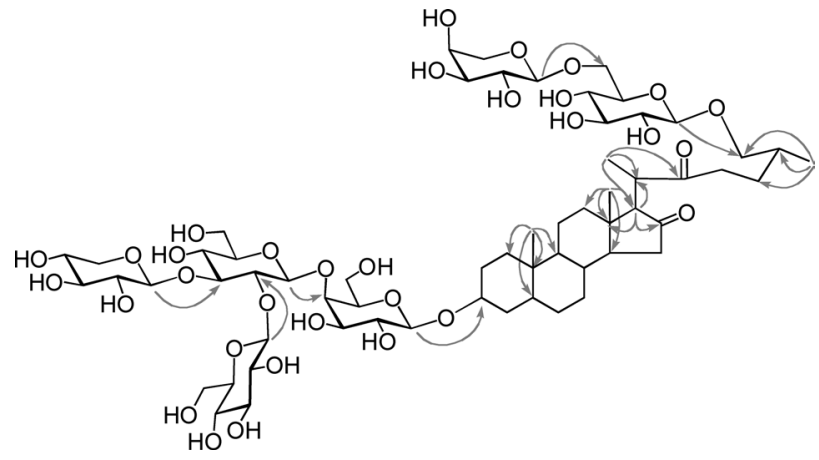

Fig. 2. ${ }^{1} \mathrm{H}-{ }^{13} \mathrm{C}$ Long-Range Correlations Observed for $\mathbf{1}$ in the $\mathrm{HMBC}$ Spectrum (in Pyridine- $d_{5}, 500 \mathrm{MHz}$ )

D-glucose, and the $\beta$-glycosidic linkage of the glucose units was confirmed to be based on the coupling constants of the anomeric protons. Consequently, the structure of 2 was concluded to be 4-hydroxyphenyl $\beta$-D-glucopyranosyl-( $(1 \rightarrow 2)-\beta$ D-glucopyranoside.

\section{Experimental}

All the instruments and materials used were the same as those cited in a previous report, ${ }^{10)}$ unless otherwise specified

Plant Material Cherry tomatoes (Senka) were grown in a hothouse and harvested in Kumamoto prefecture, Japan, in February 2003.

Extraction and Isolation The crushed fresh ripe cherry tomatoes $(1936.7 \mathrm{~g})$ were extracted with $\mathrm{MeOH}(1000 \mathrm{ml} \times 2)$ for $95 \mathrm{~d}$ at room temperature, and the solvent was removed under reduced pressure to yield a syrup $(137.8 \mathrm{~g})$. The $\mathrm{MeOH}$ extract was chromatographed over Diaion HP-20 column $\left(\mathrm{H}_{2} \mathrm{O}, \mathrm{MeOH}\right.$, and acetone) to yield fractions (frs.) 1-3. Fr. 2 (6341 mg) was subjected to Sephadex LH-20 column chromatography $(\mathrm{MeOH})$ to yield frs. 2.1-2.4. The chromatography of fr. 2.1 (3972 mg) on Chromatorex ODS column $(40 \% \mathrm{MeOH}, 50 \% \mathrm{MeOH}, 60 \% \mathrm{MeOH}, 70 \%$
Table $1 .{ }^{13} \mathrm{C}-\mathrm{NMR}$ Data for $\mathbf{1}$ (in Pyridine- $d_{5}, 125 \mathrm{MHz}$ )

\begin{tabular}{|c|c|c|c|c|c|c|c|}
\hline Ag-1 & 36.8 & Ag-19 & 12.2 & Gal-1 & 102.4 & Xyl-1 & 104.6 \\
\hline $\mathrm{Ag}-2$ & 29.7 & $\mathrm{Ag}-20$ & 43.8 & Gal-2 & 72.8 & Xyl-2 & $74.7^{a)}$ \\
\hline $\mathrm{Ag}-3$ & 77.2 & Ag-21 & 15.6 & Gal-3 & $75.2^{a)}$ & Xyl-3 & 78.1 \\
\hline $\mathrm{Ag}-4$ & 34.7 & Ag-22 & 214.1 & Gal-4 & 79.6 & Xyl-4 & 70.5 \\
\hline Ag-5 & 44.6 & Ag-23 & 37.4 & Gal-5 & $75.2^{a)}$ & Xyl-5 & 67.0 \\
\hline $\mathrm{Ag}-6$ & 28.7 & Ag-24 & 27.6 & Gal-6 & 60.7 & $\mathrm{Glc}^{\prime \prime}-1$ & 104.5 \\
\hline $\mathrm{Ag}-7$ & 32.1 & Ag-25 & 33.4 & Glc-1 & 104.6 & $\mathrm{Glc}^{\prime \prime}-2$ & 74.8 \\
\hline Ag-8 & 34.4 & Ag-26 & 75.2 & Glc-2 & 80.8 & $\mathrm{Glc}^{\prime \prime}-3$ & 78.0 \\
\hline Ag-9 & 54.0 & $\mathrm{Ag}-27$ & 17.2 & Glc-3 & 87.0 & $\mathrm{Glc}^{\prime \prime}-4$ & 71.0 \\
\hline Ag-10 & 35.7 & & & Glc-4 & 70.1 & $\mathrm{Glc}^{\prime \prime}-5$ & 76.7 \\
\hline Ag-11 & 20.9 & & & Glc-5 & 77.5 & $\mathrm{Glc}^{\prime \prime}-6$ & 69.4 \\
\hline Ag-12 & 38.9 & & & Glc-6 & 62.6 & Ara-1 & 105.0 \\
\hline Ag-13 & 42.1 & & & $\mathrm{Glc}^{\prime}-1$ & 104.3 & Ara-2 & 72.0 \\
\hline Ag-14 & 51.0 & & & $\mathrm{Glc}^{\prime}-2$ & 75.7 & Ara-3 & 74.0 \\
\hline Ag-15 & 39.7 & & & $\mathrm{Glc}^{\prime}-3$ & 78.2 & Ara-4 & 68.8 \\
\hline Ag-16 & 218.5 & & & $\mathrm{Glc}^{\prime}-4$ & 71.5 & Ara-5 & 66.3 \\
\hline Ag-17 & 66.7 & & & $\mathrm{Glc}^{\prime}-5$ & 77.8 & & \\
\hline Ag-18 & 13.1 & & & $\mathrm{Glc}^{\prime}-6$ & 62.2 & & \\
\hline
\end{tabular}

$\delta$ in ppm from TMS. a) Assignments may be interchangeable. Ag, aglycone; Gal, galactopyranosyl; Glc, glucopyranosyl; Xyl, xylopyranosyl; Ara, arabinopyranosyl.

$\mathrm{MeOH}, 90 \% \mathrm{MeOH}, \mathrm{MeOH})$ yielded frs. 2.1.1-2.1.9. Fr. 2.1.1 (1644 mg) was subjected to silica gel column [Merck. Art 9385, $\mathrm{CHCl}_{3}-\mathrm{MeOH}-\mathrm{H}_{2} \mathrm{O}$ $(10: 2: 0.1,8: 2: 0.2,8: 2: 0.1,7: 3: 0.5,6: 4: 1)]$ to yield frs. 2.1.1.12.1.1.12. Frs. 2.1.1.5 (63 mg), 2.1.1.6 (145 mg), and 2.1.1.7 (132 mg) were each subjected to HPLC (Cosmosil 5C18 AR-II, Nacalai Tesque, Inc., 250 $\mathrm{mm} \times 20 \mathrm{~mm}$ i.d.; $30 \% \mathrm{MeOH})$ to yield $\mathbf{5}(3 \mathrm{mg})$ from fr. 2.1.1.5, $9(16 \mathrm{mg})$, $6(8 \mathrm{mg})$ from fr. 2.1.1.6, and $2(7 \mathrm{mg})$ from fr. 2.1.1.7. Fr. 2.1.1.10 $(160 \mathrm{mg})$ was successively subjected to Diaion HP-20 (70\% MeOH, $80 \% \mathrm{MeOH}, 90 \%$ $\mathrm{MeOH}, \mathrm{MeOH}$ ) and HPLC [YMC-Pack Polyamine II, YMC Co., Ltd., $250 \mathrm{~mm} \times 20 \mathrm{~mm}$ i.d.; $\left.\mathrm{CHCl}_{3}-\mathrm{MeOH}-\mathrm{H}_{2} \mathrm{O}(6: 4: 1)\right]$ to yield $4(6 \mathrm{mg})$. HPLC of fr. $2.1 .5(132 \mathrm{mg})$, which was performed under the same conditions as those used for fr. 2.1.1.10, yielded $\mathbf{1}(20 \mathrm{mg})$. Fr. $2.2(1420 \mathrm{mg})$ was subjected to silica gel column [Merck. Art 9385, $\mathrm{CHCl}_{3}-\mathrm{MeOH}-\mathrm{H}_{2} \mathrm{O}$ (14: $2: 0.1,10: 2: 0.1,8: 2: 0.2,7: 3: 0.5,6: 4: 1,5: 5: 1,0: 1: 0)]$ to yield frs. 
2.2.1-2.2.8 and $7(44 \mathrm{mg})$. Fr. 2.2.1 (90 mg) was subjected to HPLC (Cosmosil 5C8 MS, Nacalai Tesque, Inc., $250 \mathrm{~mm} \times 20 \mathrm{~mm}$ i.d.; $50 \% \mathrm{MeOH}$ ) to yield $8(25 \mathrm{mg})$. The chromatography of fr. $3(1373 \mathrm{mg})$ on silica gel column [Merck. Art 9385, $\mathrm{CHCl}_{3}-\mathrm{MeOH}-\mathrm{H}_{2} \mathrm{O}(50: 1: 0,20: 1: 0,14: 2: 0.1,10$ : $2: 0.1,8: 2: 0.2,8: 2: 0.1,7: 3: 0.5,6: 4: 1,0: 1: 0)]$ yielded frs. $3.1-3.20$ and $\mathbf{3}(81 \mathrm{mg})$.

1: Amorphous powder. $[\alpha]_{\mathrm{D}}^{21}-65.8^{\circ}(c=2.3, \mathrm{MeOH})$. Positive FAB-MS $m / z: 1367[\mathrm{M}+\mathrm{Na}]^{+}$. HR-positive FAB-MS $m / z: 1367.5839[\mathrm{M}+\mathrm{Na}]^{+}$ (Calcd for $\mathrm{C}_{61} \mathrm{H}_{100} \mathrm{O}_{32} \mathrm{Na}$ : 1367.6096). ${ }^{1} \mathrm{H}-\mathrm{NMR}$ data (in pyridine- $d_{5}$, $500 \mathrm{MHz}) \delta: 5.57(1 \mathrm{H}, \mathrm{d}, J=8.0 \mathrm{~Hz}, \mathrm{H}-1$ of Glc' $), 5.19(1 \mathrm{H}, \mathrm{d}, J=8.0 \mathrm{~Hz}, \mathrm{H}-$ 1 of Xyl), $5.16(1 \mathrm{H}, \mathrm{d}, J=8.0 \mathrm{~Hz}, \mathrm{H}-1$ of Glc), $4.94(1 \mathrm{H}, \mathrm{d}, J=6.0 \mathrm{~Hz}, \mathrm{H}-1$ of Ara), $4.93(1 \mathrm{H}, \mathrm{d}, J=7.5 \mathrm{~Hz}, \mathrm{H}-1$ of Gal $), 4.77(1 \mathrm{H}, \mathrm{d}, J=8.0 \mathrm{~Hz}, \mathrm{H}-1$ of $\left.\mathrm{Glc}^{\prime \prime}\right), 1.10\left(3 \mathrm{H}, \mathrm{brd}, J=5.0 \mathrm{~Hz}, \mathrm{H}_{3}-21\right), 1.06\left(3 \mathrm{H}, \mathrm{d}, J=6.0 \mathrm{~Hz}, \mathrm{H}_{3}-27\right), 0.70$ $\left(3 \mathrm{H}, \mathrm{s}, \mathrm{H}_{3}-18\right), 0.66\left(3 \mathrm{H}, \mathrm{s}, \mathrm{H}_{3}-19\right) .{ }^{13} \mathrm{C}-\mathrm{NMR}$ data: see Table 1.

2: Amorphous powder. $[\alpha]_{\mathrm{D}}^{28}-7.9^{\circ}(c=0.4$, pyridine). Positive FAB-MS $m / z: 457[\mathrm{M}+\mathrm{Na}]^{+}$. HR-positive FAB-MS $\mathrm{m} / z: 457.1329$ (Calcd for $\mathrm{C}_{18} \mathrm{H}_{26} \mathrm{O}_{12} \mathrm{Na}: 457.1322$ ). ${ }^{1} \mathrm{H}-\mathrm{NMR}$ data (in pyridine- $\left.d_{5}, 500 \mathrm{MHz}\right) \delta: 7.46$ $(2 \mathrm{H}, \mathrm{d}, J=7.0 \mathrm{~Hz}), 7.14(2 \mathrm{H}, \mathrm{d}, J=7.0 \mathrm{~Hz}), 5.40[1 \mathrm{H}, \mathrm{d}, J=8.0 \mathrm{~Hz}, \mathrm{H}-1$ of Glc], $5.36\left(1 \mathrm{H}, \mathrm{d}, J=7.5 \mathrm{~Hz}, \mathrm{H}-1\right.$ of $\mathrm{Glc}^{\prime}$ ). ${ }^{13} \mathrm{C}-\mathrm{NMR}$ (in pyridine- $d_{5}$, $125 \mathrm{MHz}) \delta: 153.8(\mathrm{C}-1$ of $\mathrm{Ag}), 151.6(\mathrm{C}-4$ of Ag), 119.2 (C-2 of Ag, C-6 of Ag), 116.5 (C-3 of Ag, C-5 of Ag), 105.6 (C-1 of Glc), 102.1 (C-1 of $\mathrm{Glc}^{\prime}$ ), 83.3 (C-2 of Glc), 78.2, 78.0, 77.7, 77.6 (Glc-5, Glc-5', Glc-3', Glc3), 76.1 (C-2 of Glc), 71.2, 70.8 (C-4 of Glc, C-4 of Glc'), 62.3, 62.0 (C-6 of Glc, C-6 of Glc').

Acidic Hydrolysis of 1 and 2 Compounds $1(14 \mathrm{mg})$ and $2(2 \mathrm{mg})$ were each heated in $2 \mathrm{M} \mathrm{HCl}(2 \mathrm{ml})$ at a temperature of $95^{\circ}$ for $3 \mathrm{~h}$. The reaction mixture was diluted with $\mathrm{H}_{2} \mathrm{O}(10 \mathrm{ml})$ and then extracted with $\mathrm{AcOEt}$ $(10 \mathrm{ml} \times 2)$. The aqueous layer was neutralized with Amberlite MB-3 (Organo Co.) and then evaporated under reduced pressure to give a monosaccharide fraction. This monosaccharide fraction was extracted with $\mathrm{MeOH}$, and the $\mathrm{MeOH}$ extract was analyzed by HPLC under the following conditions: column, Shodex RS-Pac DC-613 $(6.0 \mathrm{~mm}$ i.d. $\times 150 \mathrm{~mm}$, Showa Denko); solvent, $\mathrm{CH}_{3} \mathrm{CN}-\mathrm{H}_{2} \mathrm{O}(3: 1)$; flow rate, $1.0 \mathrm{ml} / \mathrm{min}$; column temperature, $70^{\circ} \mathrm{C}$; detector, JASCO OR-2090 plus; pump, JASCO PU-2080; and column oven, JASCO CO-2060. The retention time $\left(t_{\mathrm{R}}\right)$ and optical activity of each of the monsaccharides were detected as follows. D-xylose $\left[t_{\mathrm{R}}(\mathrm{min})\right.$ 5.5 ; optical activity, positive], L-arabinose $\left[t_{\mathrm{R}}(\min ) 6.1\right.$; optical activity, positive], D-glucose $\left[t_{\mathrm{R}}(\mathrm{min}) 7.3\right.$; optical activity, positive $]$ and D-galactose $\left[t_{\mathrm{R}}\right.$ (min) 8.0; optical activity, positive $]$ for $\mathbf{1}$; D-glucose $\left[t_{\mathrm{R}}(\mathrm{min}) 7.3\right.$; optical activity, positive] for 2. HPLC analysis [detector, Shimadzu SP-6A (UV at $293 \mathrm{~nm}$ ); column, Cosmosil 5SL-II, Nacalai Tesque, Inc., $250 \mathrm{~mm} \times 4.6 \mathrm{~mm}$ i.d.; solvent, hexane-acetone $(3: 1)$; flow rate, $0.8 \mathrm{ml} / \mathrm{min}]$ of the AcOEt extract of the reaction mixture of $\mathbf{2}$ revealed the presence of hydroquinone $\left(t_{\mathrm{R}}\right.$ $12.4 \mathrm{~min})$. However, the AcOEt extract of the reaction mixture of $\mathbf{1}$ exhibited several spots by TLC, and the Ag of $\mathbf{1}$ was not obtained.

Acknowledgments We express our appreciation to Mr. K. Takeda and Mr. T. Iriguchi of Kumamoto University for their measurement of the MS and NMR spectra. This research was supported in part by a Grant-in-Aid for Scientific Research (C) (No. 19590030) from Japan Society for the Promotion of Science.

\section{References}

1) Fujiwara Y., Yahara S., Ikeda T., Ono M., Nohara T., Chem. Pharm. Bull., 51, 234-235 (2003).

2) Fujiwara Y., Takai A., Uehara Y., Ikeda T., Okawa M., Yamauchi K., Ono M., Yoshimitsu H., Nohara T., Tetrahedron, 60, 4915-4920 (2004).

3) Fujiwara Y., Yoshizaki M., Matsushita S., Yahara S., Abe E., Ikeda T., Ono M., Nohara T., Chem. Pharm. Bull., 53, 584-585 (2005).

4) Ono M., Takara Y., Egami M., Uranaka K., Yoshimitsu H., Matsushita S., Fujiwara Y., Ikeda T., Nohara T., Chem. Pharm. Bull., 54, 237239 (2006)

5) Ono M., Ito Y., Ishikawa T., Kitajima J., Tanaka Y., Niiho Y., Nohara T., Chem. Pharm. Bull., 44, 337-342 (1996).

6) Rosa S. D., Giulio A. D., Tommonaro G., Phytochemistry, 42, 10311034 (1996).

7) Honbu T., Ikeda T., Zhu X.-H., Yoshihara O., Okawa M., Nafady A. M., Nohara T., J. Nat. Prod., 65, 1918-1920 (2002).

8) Seo S., Tomita Y., Tori K., Yoshimura Y., J. Am. Chem. Soc., 100, 3331-3339 (1978).

9) Kasai R., Okihara M., Asakawa J., Tanaka O., Tetrahedron Lett., 1977, 175-178 (1977)

10) Yamasaki T., Kawabata T., Masuoka C., Kinjo J., Ikeda T., Nohara T., Ono M., J. Nat. Med., 62, 47-51 (2008). 